\title{
PENGUASAAN LAHAN USAHATANI PADI SAWAH DAN HUBUNGANNYA DENGAN TINGKAT PEMISKINAN DI DESA PADANG MUTUNG KECAMATAN KAMPAR KABUPATEN KAMPAR
}

\author{
Mufti dan Dedi Zargustin \\ Staff Pengajar Fakultas Pertanian Universitas Lancang Kuning \\ Email : ir.mufti@yahoo.com
}

\begin{abstract}
ABSTRAK
Penelitian ini dilakukan dengan tujuan untuk menganalisis hubungan antara luas penguasaan lahan usahatani padi sawah terhadap tingkat kemiskinan di Desa Padang Mutung Kecamatan Kampar.

Penelitian ini dilakukan di Desa Padang Mutung Kecamatan Kampar Kabupaten Kampar Provinsi Riau bulan November 2016 sampai dengan Januari 201. Anggota populasi adalah petani padi sawah yang berjumlah $310 \mathrm{KK}$, yang dibagi atas 2 strata yaitu strata I (197 KK), strata II (113 KK). Selanjutnya dari masingmasing strata diambil $10 \%$ dari anggota populasi sebagai responden yang berjumlah $32 \mathrm{KK}$.

Metode yang digunakan dalam penelitian ini adalah metode penelitian deskriptif dan kuantitatif. Data diolah meliputi data tentang pendapatan keluarga (rumah tangga). Sementara tingkat kemiskinan diukur dengan menggunakan konsep Sajogyo. Untuk menganalisis hubungan luas penguasaan lahan dengan tingkat kemiskinan menggunakan analisis Chi square. Hasil olahan data akan dianalisis sampai kepada penarikan kesimpulan dan pelaporan.

Berdasarkan hasil analisis uji Pearson Chi-Square terhadap luas lahan berdasarkan tingkat kemiskinan (tidak miskin; miskin), $\left(\chi^{2}=4,571, \mathrm{p}<0.05\right)$, menunjukkan hasil yang signifikan antara luas lahan yang dimiliki dengan tingkat kemiskinan. Ini berarti hipotesis yang menyatakan bahwa terdapat hubungan yang signifikan antara luas lahan dengan tingkat kemiskinan, diterima.
\end{abstract}

Kata kunci : kemiskinan, lahan, signifikansi, strata,

\section{PENDAHULUAN}

Tingkat penguasaan lahan petani akan mempengaruhi kepada penerimaan yang akan diperoleh petani dari hasil usahataninya. Luas lahan merupakan salah satu faktor penentu dalam proses produksi disamping faktor-faktor lainnya seperti benih, pupuk, pestisida, dan ternaga kerja. Dalam suatu usahatani termasuk usahatani padi sawah luas lahan akan mempengaruhi produksi padi sawah yang dihasilkan oleh petani. Oleh karena itu semakin sempit luas lahan yang dikuasai petani maka akan semakin rendah pula produksi yang diperoleh petani dari hasil usahataninya, begitu pula sebaliknya. 
Desa Padang Mutung merupakan salah satu desa di Kecamatan Kampar Kabupaten Kampar yang merupakan salah satu centra produksi beras di Kabupaten Kampar. Bila dilihat dari rata-rata luas lahan yang dikuasai oleh petani ternyata penguasaan lahan berada antara 0,25 - 0,45 Ha dan ini merupakan kelompok terbesar masyarakat. Hal ini menunjukkan bahwa penguasaan lahan di Kabupaten Kampar khususnya di daerah ini tergolong sempit sempit. Sempitnya luas penguasaan lahan akan berhubungan dengan tingkat kemiskinan yang berlaku pada petani. Sejauhmana hubungan antara luas penguasaan lahan dengan tingkat kemiskinan petani khusunya petani padi sawah merupakan suatu hal yang perlu dilakukan penelitian lebih lanjut.

Dari apa yang telah dikemukan di atas, maka judul daripada penelitian ini adalah “ Penguasaan Lahan Usahatani Padi Sawah Dan Hubungannya Dengan Tingkat Kemiskinan Di Desa Padang Mutung Kecamatan Kampar Kabupaten Kampar “.

\section{METODE PENELITIAN}

Penetian di laksanakan di Desa Padang Mutung Kecamatan Kampar Kabupaten Kampar. Pemilihan lokasi penelitian ini atas dasar pertimbangan bahwa pada daerah ini banyak terdapat rumah tangga yang melakukan usahatani padi sawah. Waktu penelitian selama lebih kurang tiga bulan, yaitu dari bulan November 2016 sampai dengan Januari 2017

Anggota populasi dalam penelitian ini adalah semua petani padi sawah yang terdapat di Desa Padang Mutung yang berjumlah 310 Kepala Keluarga (PPL Kecamatan Kampar, 2016).

Pengambilan sampel dilakukan dengan menggunakan metode Stratified Random Sampling, dimana dari anggota populasi tersebut di bagi ke dalam 2 strata berdasarkan kepada luas lahan yaitu :

Strata I : Golongan petani padi sawah yang memiliki luas lahan garapan 0-0,25 Ha yang berjumlah 197 KK

Strata II : Golongan petani padi sawah yang memiliki luas lahan garapan antara 0,26-0,50 Ha yang berjumlah $113 \mathrm{KK}$

Selanjutnya dari kedua strata tersebut diambil sampel untuk responden sebesar $10 \%$. Untuk menganalisis hubungan antara luas penguasaan lahan 
usahatani padi sawah dengan tingkat kemiskinan di Desa Padang Mutung, menggunakan analisis Chi Square.

\section{HASIL DAN PEMBAHASAN}

\section{Identitas Petani Responden}

Identitas petani Responden meliputi umur, tingkat pendidikan dan jumlah anggota keluarga.

\section{Umur}

Umur responden sangat bervariasi dari yang berusia muda sampai kepada umur yang sudah tua. Variasi umur ini tentu akan mempengaruhi mempengaruhi produktivitas petani dalam melakaukan usahataninya. Pada umumnya petani yang berusia relatif muda lebih produktif jika dibandingkan yang berusia tua. Pada Tabel 1 dapat dilihat distribusi umur petani responden di Desa Padang Mutung.

Berdasarkan Tabel 1 diketahui bahwa sebagian besar petani responden berada pada umur produktif yang berumur antara 43-48 tahun, dengan persentase sebesar 15,63 persen. Ini menunjukkan bahwa petani responden sangat produktif dalam melakukan usahataninya.

Tabel 1. Distribusi Umur Petani Responden Di Desa Padang Mutung

\begin{tabular}{|c|c|c|}
\hline Umur Petani Responden & Jumlah (KK) & Persentase (\%) \\
\hline$<30$ & 2 & $(6,25)$ \\
\hline $31-36$ & 1 & $(3,12)$ \\
\hline $37-42$ & 5 & $(8,06)$ \\
\hline $43-48$ & 20 & $(15,63)$ \\
\hline $49-55$ & 3 & $(9,38)$ \\
\hline$>55$ & 1 & $(3,12)$ \\
\hline Jumlah & 32 & $(100)$ \\
\hline
\end{tabular}

\section{Tingkat Pendidikan}

Tingkat pendidikan mempunyai hubungan terhadap daya adopsi petani terhadap teknologi baru. Semakin tinggi tingkat pendidikan, semakin tinggi daya nalar petani dan ini akan mempengaruhi adopsi terhadap teknologi baru.

Pada Tabel 2 diperlihatkan tingkat pendidikan petani Responden di Desa Padang Mutung. Berdasarkan Tabel 5.3 diketahui bahwa sebagian besar petani responden memiliki tingkat pendidikan SD dan SMP, tidak ada pendidikan 
perguruan tinggi. Persentase petani responden yang memiliki pendidikan SD yaitu 62,5 persen.

Tabel 2 Distribusi Tingkat Pendidikan Petani Responden Di Desa Padang Mutung

\begin{tabular}{|c|c|c|}
\hline $\begin{array}{c}\text { Tingkat Pendidikan Petani } \\
\text { Responden }\end{array}$ & $\begin{array}{c}\text { Jumlah } \\
(\mathrm{KK})\end{array}$ & $\begin{array}{c}\text { Persetanse } \\
(\%)\end{array}$ \\
\hline SD & 20 & 62.5 \\
\hline SMP & 8 & 25 \\
\hline SMU/K & 4 & 12,5 \\
\hline PT & - & - \\
\hline Jumlah & 32 & 100 \\
\hline
\end{tabular}

\section{Jumlah Anggota Keluarga}

Besar kecilnya jumlah angota keluarga sangat menentukan terhadap kemiskinan suatu rumah tangga. Jumlah anggota keluarga merupakan dasar dalam perhitungan pendapatan perkapita yang merupakan saalah satu kriteria dalam menentukan kemiskinan rumah tangga. Anggota keluarga terdiiri dari suami atau istri, anak-anak petani serta keluarga dekat yang tinggal serumah dengan petani seperti orang tua, mertua,menantu, adik dan sebagainya.

Pada Tabel 3 diperlihatkan jumlah anggota keluarga petani Responden di Desa Padang Mutung Kecamatan Kampar. Berdasarkan Tabel 3 diketahui bahwa 50 persen petani responden mempunyai jumlah anggota keluarga antara 4- 5 orang, dan 37,5 persen lebih dari 5 orang Jumlah ini sesuai dengan kriteria di dalam perhitungan pendapatan garis kemiskinan sebagaimana dikemukakan oleh Sajogyo di dalam Quibria (1996).

Tabel 3. Distribusi Jumlah Anggota Keluarga Petani Responden Di Desa Padang Mutung

\begin{tabular}{|c|c|c|}
\hline $\begin{array}{c}\text { Jumlah Anggota Keluarga } \\
\text { (orang) }\end{array}$ & $\begin{array}{c}\text { Jumlah } \\
(\text { KK) }\end{array}$ & $\begin{array}{c}\text { Persentase } \\
(\%)\end{array}$ \\
\hline$<2$ & 1 & $(3,12)$ \\
\hline $2-3$ & 3 & $(9,37)$ \\
\hline $4-5$ & 16 & $(50,00)$ \\
\hline$>5$ & 12 & $(37,5)$ \\
\hline Jumlah & 32 & $(100)$ \\
\hline
\end{tabular}

Tingkat kemiskinan rumah tangga apakah termasuk kategori miskin atau tidak, penelitian ini akan mengkategorikan rumah tangga dalam empat tingkat sesuai dengan kategori kemiskinan yang dikemukakan oleh Sajogyo (Quibria 
1996), yaitu tidak miskin, miskin, miskin sekali dan paling miskin. Harga beras Rp 7.000 per kilogram menurut standar Depot Logistik Provinsi Riau pada bulan Juni 2016 akan digunakan sebagai standar dalam penelitian ini. Pendapatan tahunan rata-rata perkapita, yaitu jumlah pendapatan rumah tangga dari semua sumber pendapatan akan digunakan untuk mengukur kategori kemiskinan di lokasi penelitian.

Berdasarkan harga beras tersebut, tingkat kemiskinan di daerah penelitian dapat dikategorikan sebagai berikut:

1. Rumah tangga paling miskin. Pendapatan tahunan rata-rata perkapita lebih kecil daripada Rp 1.260.000 atau setara dengan penggunaan kurang daripada $180 \mathrm{~kg}$ beras setahun.

2. Rumah tangga miskin sekali. Pendapatan tahunan rata-rata perkapita antara Rp 1.260.000 hingga Rp 1.680.000 setara dengan penggunaan beras antara 180 hingga 240 kilogram beras setahun.

3. Rumah tangga miskin. Pendapatan tahunan purata perkapita antara $\mathrm{Rp}$ 1.680.001 hingga $\mathrm{Rp} 2.240 .000$ atau setara dengan penggunaan beras antara 241 hingga 320 kilogram beras setahun.

4. Rumah tangga tidak miskin. Pendapatan tahunan rata-rata perkapita lebih besar daripada Rp 2.240.000 atau setara dengan penggunaan beras yang lebih banyak dari 320 kilogram setahun.

Pada Tabel 4 diperlihatkan tentang kategori kemiskinan rumah tangga di lokasi penelitian.

Tabel 4. Kategori Kemiskinan Rumah Tangga Di Desa Padang Mutung Tahun, 2016

\begin{tabular}{|l|c|c|}
\hline Kategori Kemiskinan & Jumlah Rumah Tangga & Persentase (\%) \\
\hline Miskin & 18 & 56,25 \\
Tidak Miskin & 14 & 43,75 \\
\hline Jumlah & 32 & 100 \\
\hline
\end{tabular}

Berdasarkan Tabel 4 diketahui bahwa 56,25 persen rumah tangga responden termasuk ke dalam kategori miskin, dan 43,75 persen tidak miskin. Sementara itu di Desa Padang Mutung tidak ditemukan adanya rumah tangga yang termasuk kategori miskin sekali dan paling miskin sesuai dengan kriteria sajogyo. 


\section{Hubungan Luas lahan Terhadap Kemiskinan Rumah Tangga}

Persoalan kemiskinan di dalam usahatani padi sawah tidak bisa dilepaskan dari luas lahan sawah yang dimiliki petan responden.

Dari segi luas lahan yang dimiliki petani, petani responden yang tergolong miskin sebahagian besar petani memiliki luas lahan yang relatif sempit berkisar antara 0-0,25 Ha. Kondisi ini tentu akan mempengaruhi produktivitas dari usahatani yang dilakukan.

Dari hasil analisis uji Pearson Chi-Square terhadap luas lahan berdasarkan tingkat kemiskinan (tidak miskin; miskin), $\left(\chi^{2}=4,571, p<0.05\right)$, menunjukkan hasil yang signifikan antara luas lahan yang dimiliki dengan tingkat kemiskinan. Ini berarti hipotesis yang menyatakan bahwa terdapat hubungan yang signifikan antara luas lahan dengan tingkat kemiskinan, diterima.

Ho: Tidak terdapat hubungan yang singnifikan antara luas lahan dengan tingkat kemiskinan rumah tangga.

H1 : Terdapat hubungan yang singnifikan antara luas lahan dengan kemiskinan tingkat kemiskinan rumah tangga.

\section{KESIMPULAN DAN SARAN}

\section{Kesimpulan}

1. 56,25 persen rumah tangga petani padi sawah di Desa Padang Mutung termasuk ke dalam kategori miskin, sedangkan yang termasuk ke dalam kategori tidak miskin sebanyak 43,75 persen.

2. Terdapat hubungan yang signifikan antara luas lahan dengan tingkat kemiskinan Petani padi sawah di Desa Padang Mutung $\quad\left(\chi^{2}=4,571\right.$ $\mathrm{p}<0.05)$.

\section{Saran}

1. Dintensifkan kegiatan penyuluhan sehingga petani mempunyai pengetahuan bagaimana meningkatkan produktivitas lahan sempit yang dimiliki petani sehingga akan menambah pendapatan rumah tangga.

2. Pendapatan perkapita perlu ditingkatkan melalui pembekalan ketrampilan kepada anggota keluarga yang tinggal serumah dengan petani sehingga akan memberikan kontribusi terhadap peningkatan pendapatan rumah tangga. 


\section{DAFTAR PUSTAKA}

Andi Nuhung, 2006. Bedah Terapi Pertanian Nasional, P.T BPI, Jakarta.

Badan Pusat Statistik, 2014. Berita Rasmi Statistik. No. 16/02/Th. XVII

Ihalauw, John Dan Sardi Kartoredjo, 2001. Penguasaan tanah Serta Implikasinya terhadap Kekekatan Budaya, BPFE UGM, Yogjakarta

Mudrajad Kuncoro, 2003. Ekonomi Pembangunan, Teori, Masalah dan Kebijakan. UPP AMP YKPN, Yogjakarta.

Sekretariat Pemkab Kampar, 2015. Kampar Dalam Angka, 2015

Tambunan, Tulus. 2006. Perekonomian Indonesia Sejak Orde Lama Hingga Pasca Krisis. Jakarta: Penerbit Pustaka Quantum.

Tedjoyuwono dalam Reksohadiprodjo (1988) Reksohadiprodjo, Sukanto, 2006. Ekonomi Sumber Daya Alam dan Energi, BPFE UGM, Yogjakarta

Wiradi (1984), Wiradi, Gunawan. 1984. Ketenagakerjaan Dalam Struktur Agraris di Perdesaan Jawa. Yogjakarta: Penerbit Yayasan Dian Desa.

Wiradi dalam Hagul, 2010. Ketenagakerjaan Dalam Struktur Agraris di Perdesaan Jawa. Yogjakarta: Penerbit Yayasan Dian Desa.

World Bank, 2013 dalam Zargustin, Dedi. 2015. Country At A Glance, Indonesia. World Bank Web Page (10 Oktober 2013), http://www.worldbank.org/en/country/indonesia 